\title{
Corrigendum \\ Exposure to the Selective $\kappa$-Opioid Receptor Agonist Salvinorin A Modulates the Behavioral and Molecular Effects of Cocaine in Rats
}

\author{
Elena H Chartoff, David Potter, Diane Damez-Werno, Bruce M Cohen and William A Carlezon Jr
}

Neuropsychopharmacology (2008) 33, 2550; doi:I0.I038/npp.2008.63; published online 2I May 2008

Correction to: Neuropsychopharmacology advance online publication, 9 January 2008; doi:10.1038/sj.npp.1301659

In this article, there are errors in page 7 and in the legends of figures $3,6,7$, and 8 :

page 7 ("Effects of salvA on DA Receptor AgonistInduced Locomotor Activity") left column, first paragraph, 12th line, the text 'whereas the DA D2/D3 receptor agonist 7-OH-DPAT did not significantly increase locomotor activity at the lower dose $(1.0 \mathrm{mg} / \mathrm{kg})$ but caused a trend toward an increase $(P=0.069)$ at the higher dose $(3.0 \mathrm{mg} / \mathrm{kg})$.' should be 'and the DA D2/D3 receptor agonist 7-OH-DPAT significantly increased locomotor activity at the higher $(3.0 \mathrm{mg} / \mathrm{kg})$, but not the lower $(1.0 \mathrm{mg} / \mathrm{kg})$, dose.'

Legends of Figures 3, 6, 7, and 8: the text: 'On days 1-5 and 8 , rats were treated for 1 day with...' should be 'On days $1-5$ and 8 , rats were treated once a day with...' 